\title{
Spatial Analysis of Tuberculosis Patients' Health Access in Bandar Lampung
}

\author{
Dyah Wulan Sumekar Rengganis Wardani ${ }^{1, *}$, Endro Prasetyo Wahono ${ }^{2}$ \\ ${ }^{1}$ Department of Public Health, Faculty of Medicine, University of Lampung, Jl. Soemantri Brojonegoro No. 1 Bandar Lampung 35145 \\ ${ }^{2}$ Department of Civil Engineering, Faculty of Engineering, University of Lampung, Jl. Soemantri Brojonegoro No. 1 Bandar Lampung \\ 35145
}

\begin{abstract}
Social determinants inequality causes different risk factors of tuberculosis (TB), including health access. Bandar Lampung is a city in Lampung province with highest prevalence of TB. Moreover, TB patients in the city have low social determinants. This research aimed to identify health access of TB patients in Bandar Lampung. This research was cross-sectional study that involved four community health centers that have conducted Directly Observed Treatment Shortcourse (DOTS) strategy. Population of this research was smear-positive TB patients in 2016 which recorded in the study site. Sample of this research was 255. Variable of this research was distance of samples' residences to health services which represented by straight-line of samples' residence geographical coordinate to health services. Data was collected through Geographical Positioning System and then analyzed using buffering analysis and visualizing by Geographical Information System. The results showed that more than $50 \%$ of samples have a short distance $(<1$ kilometer) to health services. Based on the results, although most TB patients in Bandar Lampung have low social determinants, they have good access to health services. Moreover, health access of TB patients can be used to support TB control program, including decreasing incidence of TB.
\end{abstract}

Keywords: Health access; tuberculosis; distance.

\section{Introduction}

Reviews and researches stated that social determinants directly or through tuberculosis (TB) risk factor influence TB infection, TB transmission as well as the outcome of TB treatment [1-4]. In most studies, social determinants correlated with education, occupation, income and social class [5]. Meanwhile, TB risk factors are more related to housing condition, food security, and health access, of the TB patients [1]. Studies related to the TB has been concluded that people with low social determinants tend to have poor housing condition, poor food security and poor health access, which then increases the risk to TB [1].

Research on poor health access shows that there is inequity of health in population [6]. People or communities with poor TB health access indicate difficultness of people or communities to obtain TB treatment of health services [1]. Research showed that geographic factors play an important role in reaching and utilization health services [6]. In low-income countries, access to health services influenced by distance which have a correlation with the time spent to access health services [7]. Moreover, poor health access also contributes to delays of decisions to look for health treatment and increases in household health's expenditure and loss of opportunity costs of incomegenerating activities $[8,9]$.
Bandar Lampung is one of the cities in Lampung Province with the highest prevalence of TB cases in 2018, with 1,676 smear-positive TB patients [10]. Furthermore, research conducted by Wardani, also stated that most of TB patients in Bandar Lampung also had low social determinants [11]. The main objective of this research is to study linkage between health access of TB patients in Bandar Lampung, which represented by distance from community health centers $(\mathrm{CHC})$ and $\mathrm{TB}$ cases. Data collected from four $\mathrm{CHC}$ were evaluated. Two of the concerned $\mathrm{CHC}$ had the highest $\mathrm{TB}$ prevalence in Bandar Lampung; meanwhile, the rest had the lowest TB prevalence in Bandar Lampung. Health access in this study refers to a straight-line distance of TB patients' residence to health services.

\section{Methods}

This research was designed as a cross-sectional study, which was conducted in four CHC namely Sukaraja, Pasar Ambon, Korpri and Susunan Baru, which have been implementing DOTS strategy. Sukaraja and Pasar Ambon represent $\mathrm{CHC}$ with a high $\mathrm{TB}$ prevalence, meanwhile Susunan Baru and Korpri represent CHC with low TB prevalence. Population of this research was all smear-positive TB patients registered at four $\mathrm{CHC}$ during the year of 2016. Sample of this research was the

\footnotetext{
* Corresponding author: dyah.wulan@fk.unila.ac.id
} 
whole population who recorded with an accurate address. The samples were recorded as 255 smear positive TB patients. In this research, health access was represented by distance to the nearest $\mathrm{CHC}$ and measured by straight-line distance from geographical coordinates of samples' residence to the concerned CHC. The distance is categorized into two groups, namely $<1$ kilometer and $1-5$ kilometers. Geographical coordinate's data were collected through ground check records using Geographical Positioning System (GPS) devices. Data was then visualized with Geographical Information System (GIS) software and was analyzed using spatial buffering analysis. This research has been receiving ethical approval from the Faculty of Medicine, University of Lampung. The respondents were also provided appropriate informed consent, and statement form that their participation is a voluntary basis.

\section{Result}

Data analysis showed that more than half $(53.2 \%)$ of TB patients' residence located at less than one kilometer from their nearest $\mathrm{CHC}$, as presented in Table 1 as well as in Figure 1, Figure 2, Figure 3 and Figure 4. Based on the table, percentage difference is slight, not more than $20 \%$.

Table 1. Distance of TB Patients to Community Health Centre in Bandar Lampung 2016

\begin{tabular}{|l|l|r|}
\hline $\begin{array}{c}\text { Community Health } \\
\text { Centers }\end{array}$ & \multicolumn{1}{|c|}{ Distance } & $\mathrm{f}(\%)$ \\
\hline Sukaraja & $<1 \mathrm{~km}$ & $59(53.2 \%)$ \\
\cline { 2 - 3 } & $1-5 \mathrm{~km}$ & $52(46.8 \%)$ \\
\hline Pasar Ambon & $<1 \mathrm{~km}$ & $59(55.1 \%)$ \\
\cline { 2 - 3 } & $1-5 \mathrm{~km}$ & $48(44.9 \%)$ \\
\hline Korpri & $<1 \mathrm{~km}$ & $13(59.1 \%)$ \\
\cline { 2 - 3 } & $1-5 \mathrm{~km}$ & $9(40.1 \%)$ \\
\hline Susunan Baru & $<1 \mathrm{~km}$ & $9(60.0 \%)$ \\
\cline { 2 - 3 } & $1-5 \mathrm{~km}$ & $6(40.0 \%)$ \\
\hline
\end{tabular}

According to the Table 1 and Figure 1, Figure 2, Figure 3 and Figure 4, although CHC Sukaraja and CHC Pasar Ambon have the highest TB prevalence (59 cases), however proportion of $\mathrm{TB}$ patients regarding their distance to $\mathrm{CHC}$ are similar with it founded for $\mathrm{CHC}$ Susunan Baru and CHC Korpri, which have lower TB prevalence compare to both CHC Sukaraja and CHC Pasar Ambon. Figure 1, Figure 2, Figure 3 and Figure 4 showed that four $\mathrm{CHC}$ also have similar spatial pattern in distance, although with different numbers of TB patients.

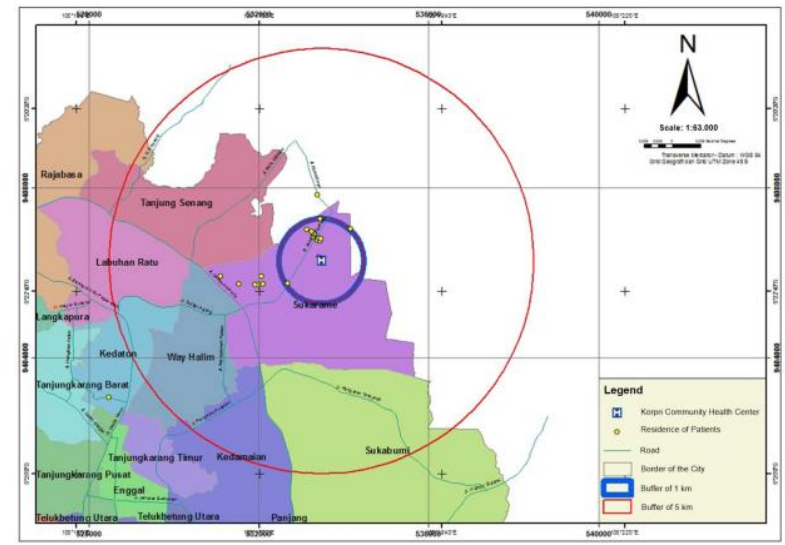

Fig. 1. Buffering of TB Patients' Residences to Korpri $\mathrm{CHC}$

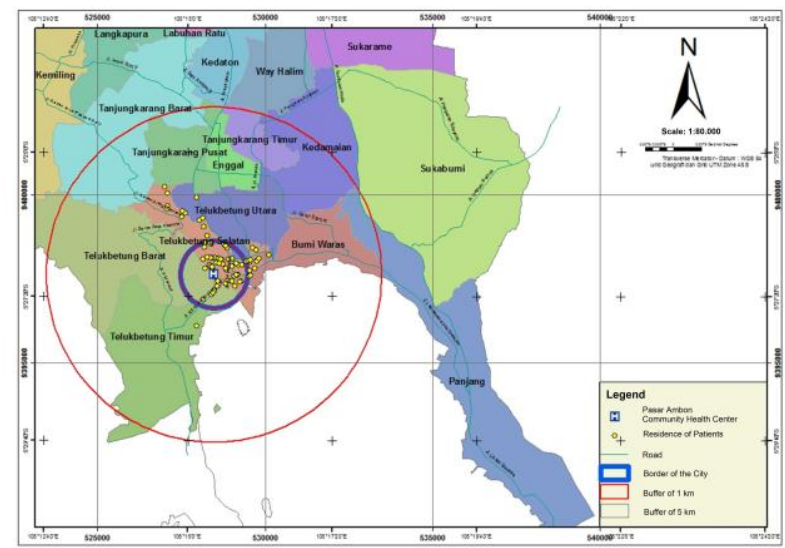

Fig. 2. Buffering of TB Patients' Residences to Pasar Ambon CHC

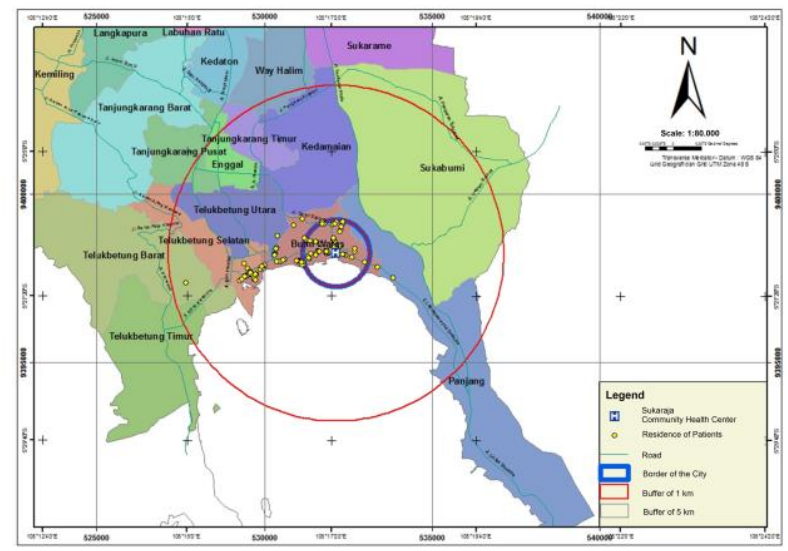

Fig. 3. Buffering of TB Patients' Residences to Sukaraja $\mathrm{CHC}$ 


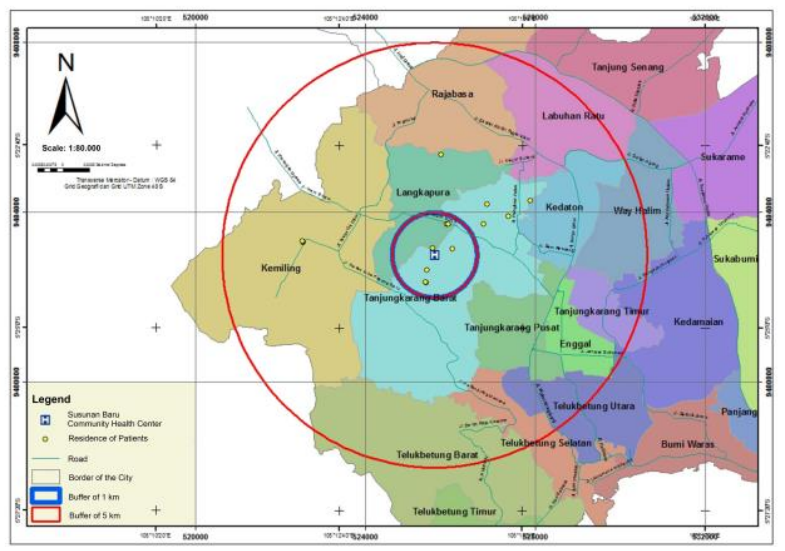

Fig. 4. Buffering of TB Patients' Residences to Susunan Baru $\mathrm{CHC}$

\section{Discussion}

In this research, generally, more than $50 \%$ of TB patients live at categorized a short distance to their nearest $\mathrm{CHC}$ (less than one kilometer), with slightly proportion difference (less than 20\%) from it on the long-distance (1 -5 kilometers). It is slightly differs from proportion $(60 \%-40 \%)$ on CHC Korpri and CHC Susunan Baru, which are considered to have lower prevalence. These results are in accordance with the efforts made by Indonesian government to bring health services closer to the community to a distance of less than one kilometer [12].

The mostly equal proportion of distance to $\mathrm{CHC}$ also indicates that TB patients in Bandar Lampung have no difficulties in accessing transportation to their nearest CHC. These results are also in concert with a study conducted in Itaborai, Brazil, which found that TB patients did not have transportation problems in reaching two Directly Observed Treatment Shortcourse (DOTS) health services [13]. On the other hand, the results differ from the research in Burkina Faso which showed that TB patients in order to reach the DOTS health services have to ride bicycles, donkeys, camels or carts [14]. This research result also contrasts with research evaluating active case finding in Chiapas, Mexico, which found variety in TB prevalence based on its distance to health services [15]. In this paper, it is found that although there is differences proportion of short distance and longdistance, the differences are insignificant.

In this paper, it is also found that although most TB patients have low social determinants they have good access, particularly distance, to health service. It is implying that Bandar Lampung, the location of this study, is typically an urban area, indicating by the location of neighboring health services in straight-line is only approximately two kilometers. Moreover, the farthest distance between respondents and health services in this study in a straight line is only 6 kilometers. In addition, there are also other health services that make it possible to bring TB patients closer to health services implementing DOTS. With this condition, it is possible that even though the TB case finding is basically passive case finding, it does not only reach TB patients who have short distance but also who live relatively away from health services. Although not learning about distance of TB patients to health services, the condition in accordance with research conducted in Afghanistan showing that patient delay in urban areas is shorter than in rural areas. Meanwhile, research conducted in Yogyakarta claimed that patient delay in the city of Yogyakarta is relatively short because it is urban areas supported by the above conditions $[9,16]$.

\section{Conclusion}

In this paper, it can be concluded that there is no significant obstacle to access the nearest CHS in Bandar Lampung. Most TB patients have good access to health services, indicating by mostly equally proportion of distance from TB patients' residence to their nearest health services, which means regardless of their residence distance, the concerned patients received mostly equal access to health services. Therefore, good access to health services can support TB control programs in reducing TB incidence, increasing cure rates and finding cases.

\section{References}

1. Lönnroth $\mathrm{K}$, Jaramillo $\mathrm{E}$, Williams BG, Dye C, Raviglione MC, Drivers of Tuberculosis Epidemics: The Role of Risk Factors and Social Determinants, Soc. Sci. Med. 68: 2240-6 (2009).

2. Wardani D, Wahono E, Predominant Determinants of Delayed Tuberculosis Sputum Conversion in Indonesia, Indian J. Community Med. 44(1): 53-7 (2019).

3. Wardani D, Wahono E, Prediction Model of Tuberculosis Transmission Based on Its Risk Factors and Socioeconomic Position in Indonesia, Indian J. Community Med. 43(3): 204-8 (2018).

4. Wardani D, Lazuardi L, Mahendradhata Y, Kusnanto H, Structured Equation Model of Tuberculosis Incidence Based on Its Social Determinants and Risk Factors in Bandar Lampung , Indonesia, Open J. Epidemiol. 4: 76-83 (2014).

5. Solar O, Irwin A, A Conceptual Framework for Action on the Social Determinants of Health. Social Determinants of Health Discussion Paper 2 (Policy and Practice), (WHO. Geneva; 2010).

6. Noor A.M, Amin A.A, Gething P.W, Atkinson P.M, Hay S.I, Snow R.W., Modelling distances travelled to government health services in Kenya, Trop. Med. Int. Heal. 11(2): 188-96 (2006).

7. Barker R.D, Nthangeni M.E, Millard F.J.C., Is The Distance A Patient Lives from Hospital A Risk Factor for Death from Tuberculosis in Rural South Africa?, Int. J. Tuberc. Lung Dis. 6(2): 98-103 (2002).

8. Ensor T, Cooper S, Overcoming barriers to health service access: influencing the demand side, Heal. Policy Plan. 19(2): 69-79 (2004).

9. Sabawoon W, Sato H, Kobayashi Y, Pardis A, Regional Differences in Delay to Tuberculosis 
Treatment in Afghanistan: A cross-Sectional Study, Appl. Geogr. 31: 1123-31 (2011).

10. Bandar Lampung Health Office, Report of Disease Prevention and Eradication: Tuberculosis 2018, (Bandar Lampung Health Office Report, Bandar Lampung, 2018).

11. Wardani D, Social Determinants and Risk Factors for Tuberculosis Patients: A Case Control Study at Health Services Applying Directly Observed Treatment Shortcourse ( DOTS) in Bandar Lampung, Indonesia, 2nd Int. Meet. Public Heal. Jakarta: KnE Life Sciences; 2018. p. 522-31 (2016).

12. National Development Plan Bureau, Increasing Community Access to More Qualified Health (2010)

13. Motta M.C.S, Villa T.C.S, Kritski J.G.A.L, Ruffi A, Silva D.F, Harter R.G, et al., Access to Tuberculosis Diagnosis in Itaborai City, Rio de Janeiro, Brazil: The Patient's Point of View, Int. J. Tuberc. Lung Dis. 13(9): 1137-41 (2009).

14. Sanou A, Dembele M, Theobald S, Macq J, Access and Adhering to Tuberculosis Treatment: Barriers Faced by Patients and Communities in Burkina Faso, Int. J. Tuberc. Lung Dis. 8(12): 1479-83 (2004).

15. Sánchez-Pérez H, Flores-Hernández J, Jansá J, Caylá J, Martín-Mateo M, Pulmonary Tuberculosis and Associated Factors in Areas of High Levels of Poverty in Chiapas, Mexico, Int. J. Epidemiol. 30: 386-93 (2001).

16. Lock W.A, Ahmad R.A, Ruiter R.A.C, van der Werf M.J, Bos A.E.R, Mahendradhata Y, et al., Patient Delay Determinants for Patients with Suspected Tuberculosis in Yogyakarta Province, Indonesia, Trop. Med. Int. Heal. 16(12): 1501-10 (2011). 